\title{
Review
}

\section{Resisting neoliberal capitalism in Chile: The possibility of social critique}

\author{
Juan Pablo Rodriguez \\ Palgrave Macmillan, 2020, xv+212pp., \\ ISBN 78-3-030-32107-9
}

Contemporary Political Theory (2021) 20, S106-S109. https://doi.org/10.1057/s41296020-00404-6; published online 25 May 2020

In Resisting Neoliberal Capitalism in Chile, Juan Pablo Rodriguez approaches the intellectual production of social movements with renewed vigour. The book proposes the concept 'critique in movements' to analyse the dynamics of resistance and opposition in student activism and housing movements (pobladores) in Chile during the last decade.

The book is divided into two parts. In the first, Rodriguez develops the concept of 'social critique,' exploring contemporary neo-Marxist theory as a social practice capable of criticizing capitalism. Drawing on thinkers like Axel Honneth, David Harvey, Fredric Jameson, and Luc Boltanski, among others, Rodriguez argues that the social critique elaborated by critical theorists can challenge the hegemony of capital and can open horizons for future transformation. In the second part, Rodriguez introduces the concept of 'critique in movements' arguing that social movements are also capable of elaborating and performing a social critique of capitalism. 'Critique in movements' describes the intellectual production that movements deploy in order to challenge neoliberalism and to prefigure political alternatives. Theoretically, the concept of critique in movements captures the tensions between a movement's agency and the resistance of capitalist structures. As Rodriguez argues, movements resist and oppose neoliberalism through a practice of social critique that includes utopian, aesthetic, and normative elements. Empirically, the concept helps to explore how movements actively oppose and resist the commodification of social life and social rights.

The concept of critique in movements allows Rodriguez to capture the limitations that social movement theory faces in understanding the processes of identification and conflict that characterized movements during the post-2008 wave of protests. Rodriguez adds to this literature by exploring how renewed critiques of capitalism, informed by Marxist thought and produced by social movements, advance our understanding of social conflict and emancipatory politics. The main

(C) 2020 Springer Nature Limited. 1470-8914 Contemporary Political Theory Vol. 20, S3, S106-S109 
contribution of Rodriguez's book is his effort to bring neo-Marxist thinking to the analysis of contemporary social movements.

The concept 'Critique in movements', thus, enables Rodriguez to address a crucial lacuna in social movement studies. As he explains, contentious politics, source mobilization, and framework theory are all instructive in analyzing the agency of movements and their immediate contexts. Yet these approaches neglect how movements relate to neoliberalism and, by extension, how movements relate to each other. Critique in movements illuminates how movements combine their experiences and intellectual development and, thereby, articulate a shared critique of neoliberalism. As Rodriguez remarks, the articulation of social critique enables movements to create new meanings of class and a common sense of identity and thus their strategic field of action.

The concept of critique in movements also provides a clue to understanding how movements can counteract neoliberal hegemony. Rodriguez argues that the new dynamics of identification and the reinvention of class are closely related to the return of massive protests as well as to the formation of broader alliances among movements seen in recent waves of unrest. For Rodriguez, the meaning of class is crystallized in activists' narratives and the symbolic production of movements. Activists draw clear lines of identification and opposition in society. The demand for social rights and the opposition to the marketization of social life make clear cuts between left-behind populations and groups that concentrate privileges and defend the status quo. The distinction between 'us' and 'them' that activists describe reveals the dynamic construction of class identity performed by movements.

With this revised concept of class, Rodriguez proposes to understand class from the perspective of movements, exploring how movements describe themselves, how they negotiate and produce a common identity, and how they define and criticize neoliberalism. From this fresh perspective, students and pobladores, who are fighting in the periphery of the class struggle, appear suddenly as the vanguard of resistance, subverting the process of class construction and reinventing class through new experiences of commonality, mutual identification, and opposition. As Rodriguez puts it, 'the possibility of a social critique in the Chilean context is related to the capacity of the social movements to rise towards generality and detotalize the dynamics of neoliberal capitalism in the areas of housing and higher education by mapping their contradictions and their crises' (p. 209).

While Rodriguez's development of the notion of critique in movements constitutes a significant theoretical contribution to social movement studies, the book fails to sufficiently address important questions of the contemporary debate. For instance, the concept of critique in movements tends to neglect the politicaleconomic dimensions of class and evades questions of distribution and misrecognition. Understanding how the distinctive patterns of distribution under neoliberalism are related to processes of class identification is critical to resolve tensions

(c) 2020 Springer Nature Limited. 1470-8914 Contemporary Political Theory Vol. 20, S3, S106-S109 S107 
between identity politics and class politics. While Rodriguez is right that capitalism is not simply an external positivity that produces movements, there is nevertheless a familiar dynamic of capitalist distribution that social movements across the world confront and oppose. As Rodriguez shows, movements are embedded in different sites of struggle that do not always converge, despite the existence of shared opponents and mutual identifications. The variability and fragility of common identities grounded in different economic positions complicate facile redefinitions of the links between class determination and class identification, which, unfortunately, the book leaves unexplored.

Moreover, the book does not examine the complex interactions between neoliberal agency and the distributive impact of social policy. The interactive relationships between social movements and sectoral policies reveal that the dynamics of class construction are always embedded in sectoral economies and in politics governed by government action and public policy. In this context, social policy enacts neoliberalism and serves to intervene in the dynamics of class identification of movements directly. For example, the existence of distributive and subsidiary policies in education and housing have forcibly shifted the political economy of social sectors on several occasions. These policies, in turn, have altered processes of identification and alliance formation between movements. The divisions and tensions between movements expose the fragility and provisional nature of class construction as well as the complex forms that neoliberalism takes to counterbalance movements' opposition. Such adjustments are particularly relevant in the field of housing and education where waves of protests have been met with the implementation of new policies that successfully divided or appropriated movements' demands through new forms of credit or public subsidies.

Beyond these omissions, however, the emphasis that Rodriguez places on the ability of movements to unify and combine their struggles illuminates one of the key characteristics behind the new wave of protests. The yellow-vests movement, extinction rebellion, and the national revolts in countries like Chile and Ecuador that have emerged since 2018 represent instructive cases in which alliances and new meanings of class can overcome the tendencies toward fragmentation derived from the diversity of socio-economic positions in which movements are embedded. This suggests that movements are learning how to take advantage of vast and diverse inequalities resulting from class structuration. New social movements are able to generate, broad, inclusive and pluralist meanings of class. With this new dynamic of identification, movements appear capable of reversing neoliberal tendencies towards fragmentation and co-optation.

It is no accident that Rodriguez focuses on Chile, a country that is widely recognized as one of the earliest and most acute implementations of neoliberalism in the world. Recently Chile has come into the global spotlight for massive waves of protest and anti-neoliberal struggles. The 2011 Chilean protests, for instance, were part of the vanguard of a global wave of unrest and offered an essential case

S108 다 2020 Springer Nature Limited. 1470-8914 Contemporary Political Theory Vol. 20, S3, S106-S109 
study for understanding anti-neoliberal movements. In light of this, Rodriguez insists that countries in the periphery of the capitalist system are paradigmatic for understanding the contemporary dynamics of neoliberal opposition. The trajectories of the struggles of students and pobladores in Chile that Rodriguez examines reveal how new meanings of class, as well as the actions of broader social movements, can converge from even the most ferocious forms of neoliberalism. His analysis takes on added significance today, after the revolt of October 2019, when the eyes of the world once again turn to Chile to see whether the place where neoliberalism was born will also be the place where it is transformed.

Publisher's Note Springer Nature remains neutral with regard to jurisdictional claims in published maps and institutional affiliations.

Hector Rios-Jara

University College London, London WC1E 6BT, UK hector.rios.18@ucl.ac.uk 